\title{
Bacterial Sialyltransferases
}

\section{細菌由来のシアル酸転移酵素}

\author{
Yamamoto, Takeshi*; Takakura, Yoshimitsu ; and Tsukamoto, Hiroshi \\ JAPAN TOBACCO INC. Glycotechnology Business Unit, 700, Higashibara, Iwata, Shizuoka 438-0802, Japan \\ *Corresponding author
}

FAX: 81-538-33-6046, E-mail: takeshi.yamamoto@ims.jti.co.jp

Key Words: sialyltransferase, marine bacterium, Genus Photobacterium, Genus Vibrio

\begin{abstract}
Although chemical glycosylation has certain advantages compared with enzymatic glycosylation in respect of its high flexibility and wide applicability, the reaction processes are complicated in many cases because the chemical reactions require multiple protection/ de-protection steps.

On the other hand, enzymatic glycosylation using glycosyltransferases is a single step process with high position- and anomer-selectivity and reaction yield. However, glycosyltransferases available for this purpose had been very limited and costly. Since then, progress has been made in the search of prokaryotic glycosyltransferases, increasing the types of enzymes that can be employed in synthesis and modification of sugar chains. Moreover, various studies have been making sugar nucleotides, which are donor substrate for the glycosyltransferases, less and less expensive.

Sialic acids are present in a variety of glycoproteins and glycolipids, often at the non-reducing termini of carbohydrate chains. It has been demonstrated that sialic acids play very important roles in various biological and physiological events. Ample supply of sialosides and sialyl-glycoconjugates is indispensable to the study of their biological functions in detail. Transfer of sialic acids by sialyltransferases to appropriate substrates in the final step under a mild reaction condition can prepare these materials in quantity. Therefore, one of the most important tasks in the study of glycobiology is to provide a large amount of bacterial sialyltransferases with diverse characteristics at low prices.
\end{abstract}

要 約

化学合成法によるグリコシル化は、糖転移酵素を用いる 方法と比較して広い適応性があり、高い柔軟性があるという 利点がある。しかしながら、化学合成法によるグリコシル化 は、保護・脱保護が必要なことからその工程が必然的に煩雑 となるという問題がある。

一方、糖転移醰素を用いるグリコシル化は、反応が一段 階で終了し、反応収率が高く立体特異性も高い。しかしなが らこれまでは反応に用いる糖転移酵素の種類が限られている という問題があったが、微生物由来の各種糖転移酵素に関す る研究の進展により、糖鎖合成/糖鎖修飾に使用可能な酵素の 種類は増加しつつある。一方、糖転移酵素の糖供与体基質で ある糖ヌクレオチドが非常に高価であるという問題も、様々 な研究開発により徐々に解決されつつある。

シアル酸は複合糖質糖鎖の非還元末端に存在することが 多い糖であり、シアル酸を含む複合糖質が生体内で様々な役 割を有していることが多くの研究により示されている。シア ル酸転移酵素を用いるシアリル化は、反応の最終段階におい て、簡便かつ温和な条件でシアル酸を目的物に導入すること が可能な方法である。そのために安定で大量調製が可能な細 菌由来のシアル酸転移酵素は、最も需要の高い糖転移酵素の 一つと考えられている。

\section{A. はじめに}

動物細胞の表層には、糖蛋白質や糖脂質などの複合糖質 が存在し、それらの糖質部分は細胞間の認識機構や細胞の分 化など重要な生命現象に深く関与していることが明らかにさ れている $(1 、 2)$ 。それらの複合糖質糖鎖は、いずれも各種の糖 転移酵素によって生合成される $(3,4)$ 。ヒトの場合、これまで に 150 種類以上の糖転移酵素遺伝子がクローニングされてい る。それらの内、一部の酵素についてはE. coli を宿主とした 
encoding glycosyltransferases have been cloned so far, and most of them have been produced as recombinant enzymes retaining the activity by protein expression systems using cultured mammalian cells, such as Chinese hamster ovary (CHO) cells. A few mammalian glycosyltransferases have been overexpressed as active enzymes in Escherichia coli, but most of those genes could not be expressed as active enzymes in $E$. coli. Therefore, abundant supply of mammalian glycosyltransfarases has not been available yet.

It has also been revealed that glycoconjugates, such as lipooligosaccharides (LOS), lipopolysaccharides (LPS) and glycoproteins, are present on the surface of bacteria and viruses $(5,6)$. In particular, the sugar chain structures of glycoconjugates in human pathogens have well been studied. It has been demonstrated that bacterial pathogens have evolved to escape immune systems of hosts by mimicking surface carbohydrates of the host cells, which are crucial for self/non-self recognition and that the glycoconjugates of the pathogens are involved in the virulence and adhesion to the host cells (7). Glycosylation of proteins has been considered to be specific to eukaryotes until very recently. However, recent progress has revealed that glycoproteins are present in prokaryotes as well $(8,9)$, although bacterial $N$-linked sugar chains differ structurally from the eukaryotic counterparts. Furthermore, evidence was provided that protein glycosylation pathways similar to those in eukaryotes exist in Gram-negative bacteria. A functional $N$-linked glycosylation pathway of a Gram-negative bacterium was transferred into $E$. coli (10). Therefore, it is likely that bacterial glycosylation capability can be modified so that human-type glycosylated-proteins will be expressed in E. coli. in the near future. Moreover, studies of glycosyltransferases from diverse bacteria have been quite active lately (11) and a number of types of carbohydrate chains have been synthesized using bacterial enzymes (12, 13).

In general, bacterial enzymes are more stable and productive in $E$. coli expression systems than mammalian enzyme. Furthermore, it has been reported that bacterial glycosyltransferases have broad acceptor substrate specificity compared with mammalian glycosyltransferases. Therefore, bacterial enzymes are expected to serve as good tools for synthesis and modification of glycans (14).

Sialic acids often occur at non-reducing termini of carbohydrate chains of glycoconjugates and are one of the most important monosaccharides $(15,16)$. Sialylation is reported to make half-lives of protein much longer in mammals. For example, introduction of two more sialylatedglycans by genetic engineering to erythropoietin, which has three of the sialylated-glycans in the native form, extended considerably the half-life in blood compared to the native protein (17). Another example is insulin with sugar chais.
蛋白質生産系を用いて大量調製が可能であるが、その他大部 分の酵素については、E. coli を宿主とした蛋白質生産系で活性 型酵素として発現させることは困難である。

一方、細菌やウイルスなどにおいてもその細胞表層には、 リポオリゴサッカライド(LOS)/リポポリサッカライド(LPS)、 糖蛋白質などの形で糖質が存在することが明らかにされてい る $(5 、 6)$ 。中でもヒトに対して病原性を有する細菌については 詳細な研究がなされており、それら病原性細菌は宿主細胞の 表面糖鎖構造を模做することにより免疫系から逃れるように 進化してきたこと、またそれらの細胞表層に存在する複合糖 質は、宿主への接着などに関与することが明らかにされてい る(7)。近年まで、蛋白質の糖鎖修飾は真核生物にのみ見られ る特徵と考えられていた。しかし、細菌においても糖鎖修飾 された糖蛋白質、糖ペプチドが存在すること $(8 、 9)$ 、哺乳動物 と比べその糖鎖構造は異なるものの、哺乳動物とよく似た蛋 白質の修飾系が存在すること等が最近になり示された (10)。 今後、これら研究の進展により、細菌を用いた蛋白質生産系 においても、目的とする糖鎖を付加できる可能性がある。ま た、ヒト型の複合糖質糖鎖の合成に利用することが期待でき る糖転移酵素も数多く取得されている(11)。更に、それらを 用いて様々な糖鎖が合成されている $(12 、 13)$ 。

一般に、細菌由来の酵素は、哺乳動物由来の酵素と比較 して、E. coli を宿主とする蛋白質生産系で活性型酵素として大 量調製が可能であり、蛋白質として安定な酵素が多い。更に これまでに明らかにされた細菌由来の糖転移醳素は、哺乳動 物由来の糖転移醭素と比較した場合、総じて糖受容体基質特 異性が広いことが示されており、各種の有用糖鎖合成のツー ルとして期待される(14)。

シアル酸は複合糖質糖鎖の非還元末端に存在することが 多い糖であり、糖鎖を構成する糖の中でも重要な糖の一つで ある $(15 、 16)$ 。それを示す具体例の一つとして、次の事例が挙 げられる。本来シアル酸含有糖鎖を有する糖蛋白質に、更に シアル酸含有糖鎖を導入した場合、本来の糖蛋白質と比べて シアル酸含有糖鎖数を増加させた改変糖蛋白質の生体内での 半減期が長くなることが明らかにされている。より具体的に は、例えばエリスロポエチン $(\mathrm{EPO})$ には本来 $N$ - 結合型糖鎖が 3 箇所に存在するが、遺伝子工学的手法を用いて $N$ - 型糖鎖の 結合箇所を増加させた糖鎖改変 EPO が開発された。この改変 された EPO は、血中での持続時間が増加することが示されて いる(17)。また、本来糖鎖修飾を受けていない単純蛋白質で あるインシュリンにシアル酸を含む糖鎖を付加させることで、 
Insulin is composed of two polypeptide chains and not naturally glycosylated. Several types of sialylated insulin were prepared by chemoenzymatic approach and tested for the blood-glucose-lowering activity, and the modified insulin showed prolonged effects compared to the native hormone (18).

In this article, we briefly review recent progress in the study of bacterial glycosyltransferases, focusing on transferases for the important monosaccharide, sialic acids, especially on $\alpha 2,3$ - and $\alpha 2,6$-sialyltransferases obtained from marine bacteria in our laboratory, which are very useful tools for the syntheses of sialosides.

\section{B. Bacterial Glycosyltransferases}

Glycosylation of proteins had generally been thought to be restricted to eukaryotes. However, recent studies have revealed that glycoproteins are present also in prokaryotic organisms $(8,9)$. Many bacterial glycosyltransferases have now been reported (11). In Table I, bacterial enzymes with confirmed glycosyltransfer activities are listed. Most of the organisms in the table are bacteria pathogenic to animals.

A gene cluster, which appeared to be involved in the glycosylation of multiple proteins, was identified in an enteric pathogen, Campylobacter jejuni. Furthermore, it was clearly demonstrated that the transfer of the cluster to $E$. coli resulted in a functional $N$-linked glycosylation pathway in $E$.
その血糖值抑制効果作用を持続的に発現させることも示され ている(18)。

我々の研究グループでは、グリコシル化の中でも化学合 成では比較的困難なシアリル化に適用することが期待でき、 更に大量調製が可能な細菌由来のシアル酸転移酵素について 研究を行っている。本稿では、我々の研究グループで最近得 られた海洋性細菌由来の $\alpha 2,3-$ 及び $\alpha 2,6$ - シアル酸転移酵素に 関する知見を中心に、近年報告された微生物由来の糖転移酵 素の進展について簡単に述べる。

\section{B. 細菌由来の糖転移酵素について}

これまでは、蛋白質の糖鎖修飾は真核生物にのみ見られ る特徵と考えられていた。しかし、研究の進展により、細菌 においても糖鎖修飾された糖蛋白質が存在することが明らか にされた $(8 、 9)$ 。また、多くの糖転移酵素が種々の細菌から得 られている(11)。

以下に細菌由来の糖転移酵素の内、ヒト型糖鎖の合成に 利用可能と考えられる酵素を示す $($ 表 I $)$ 。それらの多くは、哺 乳動物の病原性細菌からクローニングされている。

Campylobacter jejuni において、哺乳動物とよく似た蛋白質 の糖鎖修飾系が存在すること等が明らかにされた。其体的に

Table I. Glycosyltransferases produced by bacteria.

\begin{tabular}{lcc}
\hline Enzyme name & origin & Reference \\
\hline Sialyltransferase & Neisseria gonorhoeae & 21 \\
& Neisseria meningitides & 21 \\
& Campylobacter jejuni & 22 \\
& Escherichia coli & 23 \\
& Photobacterium damselae & 24 \\
& Pasteurella multocida & 25 \\
Galactosyltransferase & Haemophilus influenzae & 26,27 \\
& Streptococcus agalactiae & 28 \\
& Neisseria gonorhoeae & 31 \\
& Neisseria meningitides & 32 \\
& Campylobacter jejuni & 33 \\
& Streptococcus agalactiae & 34 \\
Fucosyltransferase & Escherichia coli & 35 \\
& Helicobacter pylori & 36 \\
N-acetylgalactosaminyltransferase & Streptococcus pnemoniae & 37 \\
& Helicobacter pylori & $38,39,40$ \\
& Bradyrhizobium sp. & 41 \\
& Rhizobium sp. & 42
\end{tabular}


coli (10). A similar gene cluster was also reported for pilin $O$-glycosylation in Neisseria meningitides $(19,20)$.

Genes for sialyltransferases were cloned from $N$. gonorhoeae (21), N. meningitides (21), C. jejuni (22), E. coli (23), Photobacterium damselae (24), Pasteurella multocida (25), Haemophilus influenzae $(26,27)$ and Streptococcus agalactiae (28). Among these enzymes, their three dimensional structures of $\alpha 2,3$-sialyltransferase (CstII) from $C$. jejuni and $\alpha 2,3$-sialyltransferase $(\Delta 24 \mathrm{PmST} 1)$ from $P$. multocida, their structures were determined by $\mathrm{X}$-ray crystallography $(29,30)$. In the case of CstII, it was reported that a histidine and two tyrosine residues were involved in substrate binding and glycosyl transfer (29), and structural difference between CstII and $\Delta 24 \mathrm{PmST} 1$ were reported (30). In addition, a high level production system of multi-functional $\alpha 2,3$-sialyltransferase (tPm0188Ph) from P. multocida was constructed (25).

The genes of galactosyltransferases were cloned from $N$. gonorhoeae (31), N. meningitides (32), C. jejuni (33), $S$. agalactiae (34), E. coli (35), Helicobacter pylori (36) and $S$. pnemoniae (37). As for fucosyltransferases, genes were cloned from $H$. pylori $(38,39,40)$, Bradyrhizobium sp. (41) and Rhizobium sp. (42). With $\mathrm{N}$-acetylglucosaminyltransfera ses, genes were cloned from $N$. meningitides (43), H. ducreyi (44) and Staphylococcus aureus (45). Genes for $N$-acetylgala ctosaminyltransferases were cloned from $N$. meningitides (43) and $H$. influenzae (46).

\section{Screening for Bacterium Producing Sialyltransferase}

Our research group has been screening a large number of bacteria for novel glycosyltransferase activities. The screening method of sialyltransferase was as follows. From the many kinds of samples, such as seawater, sea sand and fishes, many bacteria were isolated. Normally, Marine broth 2216 was used as the culture medium. One colony of isolated bacteria on a Marine broth 2216-agar plate were inoculated into $5 \mathrm{ml}$ of Marine broth 2216 medium in a $30 \mathrm{ml}$ test tube and cultivated at $30^{\circ} \mathrm{C}$ for $12 \mathrm{~h}$ on a rotary shaker (150rpm) each. After cultivation, those cells were recovered by centrifugation and suspended in extraction buffer. The suspended cells were sonicated until absorbance at $600 \mathrm{~nm}$ became $30 \%$ of that of the cell suspension. The sonicated solutions were used as crude enzyme solution. Sialyltransferase activity was routinely assayed by measuring $\left[4,5,6,7,8,9-{ }^{14} \mathrm{C}\right]-\mathrm{NeuAc}$ transferred from CMP-[4,5,6,7,8,9$\left.{ }^{14} \mathrm{C}\right]-\mathrm{NeuAc}$ as a donor substrate to lactose as an acceptor substrate. The standard reaction mixture consisted of $70 \mathrm{nmol}$ of CMP-[4,5,6,7,8,9- $\left.{ }^{14} \mathrm{C}\right]-\mathrm{NeuAc}$ (about $650 \mathrm{cpm} / \mathrm{nmol}$ ), 1.25 $\mu \mathrm{mol}$ of lactose, and crude enzyme solution in $25 \mu \mathrm{l}$ of $20 \mathrm{mM}$ sodium cacodylate buffer ( $\mathrm{pH} 6.0$ ) containing $0.02 \%$ Triton $\mathrm{X}-100$. The enzyme reaction was carried out at $30^{\circ} \mathrm{C}$ for 60
は、Saccharomyces cerevisiae が生産するオリゴサッカライド転 移酵素のサブユニットと相同性が見られる蛋白質をコードす る遺伝子が発見され、更に糖転移酵素と相同性の高いアミノ 酸配列をコードする複数の遺伝子がクラスターを形成してい ることが明らかにされた。この遺伝子クラスターを大腸菌に 導入した結果、大腸菌内で $N$ - 結合型糖鎖が生産されることが 明らかにされた(10)。また、Neisseria meningitidisに扔いても 同様の遺伝子クラスターが報告されている $(19,20) 。$

シアル酸転移酵素は、最も多くの種類の細菌から遺伝子 がクローニングされている糖転移酵素である。これまでに Neisseria gonorhoeae (21)、N. meningitides (21)、C. jejuni (22)、E. coli (23)、Photobacterium damselae (24)、Pasteurella multocida (25)、Haemophilus influenzae (26,27)、Streptococcus agalactiae (28)等から遺伝子が取得されている。これらの内、これまで にC. jejuni の $\alpha 2,3$ - シアル酸転移酵素 (CstII) 及び P. multocida 由来のシアル酸転移酵素 $(\Delta 24 \mathrm{PmST} 1)$ については、それらの 結晶構造が解析されている $(29,30)$ 。C. jejuni の $\alpha 2,3-$ シアル 酸転移酵素 (CstII) においては、基質の結合と糖転移反応に His 残基と 2 つ Tyr 残基が重要であることが示されている(29)。 一方、また、Pasteurella multocida 由来の $\alpha 2,3-$ シアル酸転移酵 素 $(\triangle 24 \mathrm{PmST} 1)$ の構造解析結果から、細菌由来の 2 種類のシ アル酸転移䤉素は、立体構造的に相違があることが報告され ている。更に、P. multocida 由来の $\alpha 2,3$ - シアル酸転移酵素遺 伝子を用いた、極めて高い酵素発現系が構築されている $(25)$ 。

ガラクトース転移酵素は、N. gonorhoeae (31)、N. meningitidis (32)、C. jejuni (33)、S. agalactiae (34)、E. coli (35)、 Helicobacter pylori (36)、Streptococcus pnemoniae (37) 等から遺 伝子が得られている。フコース転移酵素に関しては、H. pylori (38、39、40)、Bradyrhizobium sp. (41)、Rhizobium sp. (42)等か ら遺伝子が得られている。 $N$ - アセチルグルコサミン転移酵素 に関しては、N. meningitides (43)、Haemophilus ducreyi (44)、 Staphylococcus aureus (45) 等から遺伝子が得られている。Nアセチルガラクトサミン転移酵素に関しては、N.meningitides (43)、H. influenzae (46) 等から遺伝子が得られている。各種細 菌のゲノム解析の進展に伴い、今後も新たな細菌由来の糖転 移酵素が取得されると考えられる。

\section{C. シアル酸転移酵素を生産する細菌の探索}

我々のグループでは、様々な細菌を対象に現在もシアル 酸転移䣼素を含む各種糖転移酵素の探索を実施している。シ アル酸転移酵素を有する微生物のスクリーニング方法を簡単 に示す。まず、海水、海砂や各種魚類等から各種微生物の単 離を行なった。通常、これら微生物の培養には Marine broth 2216 培地を使用した。上記の方法で得られた各種微生物を Marine broth 2216 寒天培地で生育させ、それぞれの微生物を Marine broth 2216 液体培地を用いて、 $30^{\circ} \mathrm{C} て ゙$ 約 12 時間それぞ れ培養した。培養終了後、遠心分離によって菌体を集め抽出 緩衝液に懸濁した。その後、この細胞懸濁を超音波により破 砕して、粗酵素溶液として用いた。シアル酸転移活性は、糖 受容体基質としてラクトースを用いて、 ${ }^{14} \mathrm{C} て ゙$ 標識した糖供 与体基質 CMP-[4,5,6,7,8,9- $\left.{ }^{14} \mathrm{C}\right]$ - シアル酸からラクトースへ転 


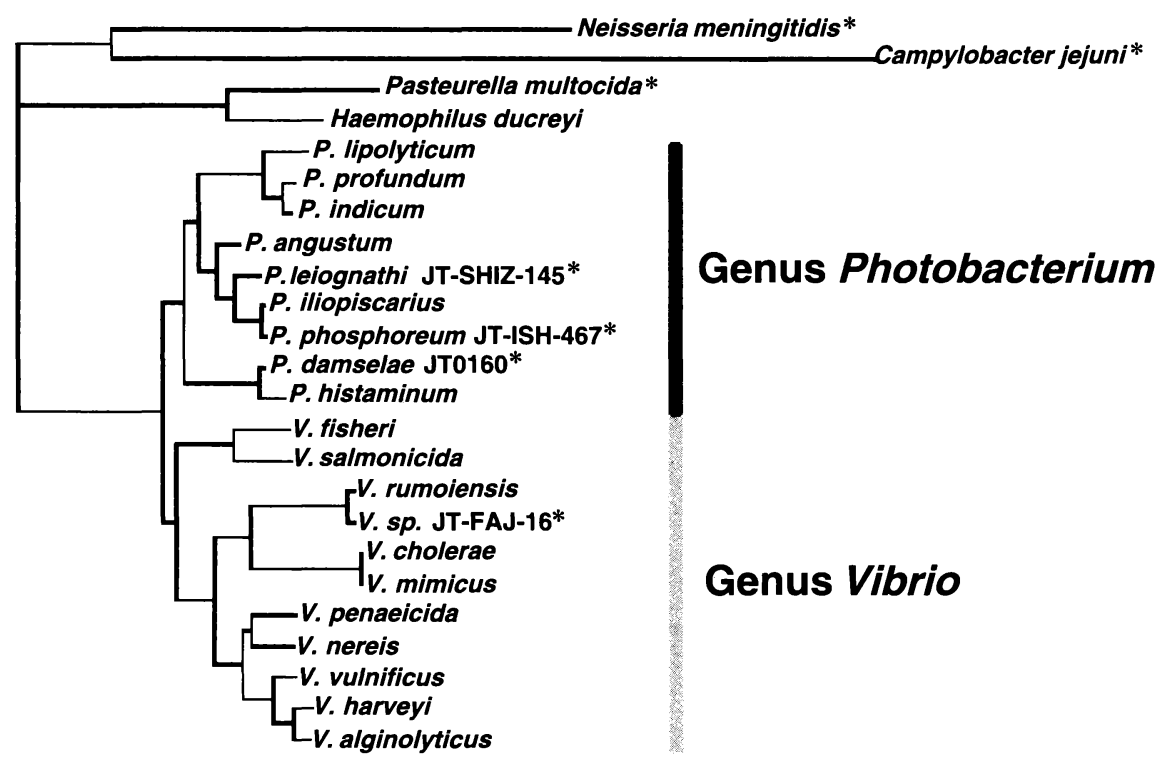

Fig. 1. Phylogenetic analysis of $16 S$ rRNA gene sequence. *: Sialyltransferase gene cloned.

min. After the reaction, the reaction mixture was diluted with $5 \mathrm{mM}$ sodium phosphate buffer ( $\mathrm{pH} \mathrm{6.8)}$ to $2 \mathrm{ml}$, and applied to a column $(0.5 \times 2 \mathrm{~cm})$ of Dowex $1 \mathrm{X8}$ (phosphate form). The eluate $(2 \mathrm{ml})$ was collected directly into a scintillation vial for counting. The radioactivity of $\left[4,5,6,7,8,9-{ }^{14} \mathrm{C}\right]-\mathrm{NeuAc}$ which had transferred to the acceptor substrate in the eluate was measured with liquid scintillation counter and the amount of NeuAc transferred was calculated.

During the course of the study, we have isolated over 20 bacteria that produce sialyltransferase. Bacteria that were probably new species were found among them. A result of phylogenetic analysis of 16S rRNA gene sequence of bacteria is displayed in Figure 1. It was evident in our study that many of the bacteria that produced sialyltransferases were classified in genus Photobacterium or closely related genus Vibrio. For instance, $P$. phosphoreum JT-ISH-467, Photobacterium sp. JT-ISH-224 and Vibrio sp. JT-FAJ-16 showed $\alpha 2,3-$ sialyltransferase activity. $P$. leiognathi JT-SHIZ-145 and $P$. damselae JT0160 expressed $\alpha 2,6$-sialyltransferase activity. These sialyltransferases showed unique acceptor substrate specificity as described in the next section.

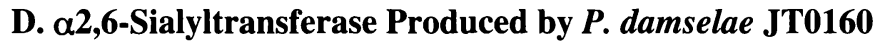

$P$. damselae JT0160 had been the only bacterium identified then that naturally had $\alpha 2,6$-sialyltransferase activity before our large scale screening (47). The only other bacterial protein with $\alpha 2,6$-sialyltransferase activity had been the $\alpha 2,3$-sialyltransferase that had been cloned from $N$. meningitides and modified by substitution of amino acids to convert the enzyme to a bi-functional enzyme with both $\alpha 2,3$-sialyltransferase and $\alpha 2,6$-sialyltransferase activity (48). The $\alpha 2,6$-sialyltransferase of $P$. damselae JT0160 was
移された $\left[4,5,6,7,8,9-{ }^{14} \mathrm{C}\right]-$ シアル酸を測定することで検出し た。標準的な酵素反応溶液 $(25 \mu \mathrm{l})$ は、70 nmol の CMP- シアル 酸、 $1.25 \mu \mathrm{mol}$ のラクトースと粗酵素溶液からなる。酵素反応 を $30^{\circ} \mathrm{C} 、 60$ 分間行ない、その後 $5 \mathrm{mM}$ のリン酸緩衝液 ( $\mathrm{pH} 6.8$ ) で $2 \mathrm{ml}$ に希釈した。この希釈された酵素反応溶液をDowex $1 \mathrm{X} 8$ (リン酸型) のカラム $(0.5 \times 2 \mathrm{~cm})$ に供して、溶出溶液を 直接シンチレーションバイアルに集めて、その放射活性を液 体シンチレーションカウンターにより検出して、転移された $\left[4,5,6,7,8,9-{ }^{14} \mathrm{C}\right]-$ シアル酸量を算出した。

これまでのところ、シアル酸転移酵素については P. damselae JT0160 株以外に約 20 菌株程度、シアル酸転移酵素を生 産する菌株を単離している。ここに、シアル酸転移酵素を生 産する数種類の菌株を含むPhotobacterium 属細菌を中心とし た細菌の系統樹を示す(図 1)。我々の研究によってPhotobacterium 属細菌、その近縁の Vibrio 属の細菌にシアル酸転移酵 素を生産する菌株が比較的多いことが明らかになってきた。 これら菌株の中には、 $\alpha 2,3-$ シアル酸転移酵素を生産する菌株 (例えば、Photobacterium phosphoreum JT-ISH-467 株) と $\alpha 2,6$ シアル酸転移酵素を生産する菌株(例えば、Photobacterium leiognathi JT-SHIZ-145 株) 等が存在する。これらのシアル酸転 移酵素は特徵的な基質特異性を有している酵素が多い。それ らの基質特異性について、次項以下で簡単に述べる。

\section{P. damselae 由来 $\alpha 2,6$ - シアル酸転移酵素}

これまでに、本来生体内で $\alpha 2,6$ - シアル酸転移酵素を生産 する細菌としては、P. damselae が報告されているのみである (47)。N. meningitides が生産する $\alpha 2,3-$ シアル酸転移酵素につ いては、その内部アミノ酸の置換により $\alpha 2,6$ - シアル酸転移活 性を示すことが報告されている (48)。P.damselae の生産する $\alpha 2,6-$ シアル酸転移酵素は、菌体から酵素を抽出する際に界面 活性剂が必須であったことから、菌体内においては膜結合型 酵素として存在すると想定された。我々はこの菌株からシア 
Table II. Monosaccharide and disaccharide acceptor specificity of sialyltransferase produced by Photobacterium damselae JT0160.

\begin{tabular}{lc}
\hline Acceptor substrate (20mM) & NeuAc transferred (nmol/min) \\
\hline Methyl $\alpha$-D-galactopyranoside & $\mathbf{0 . 1 2}$ \\
Methyl $\beta$-D-galactopyranoside & $\mathbf{0 . 3 5}$ \\
Methyl $\alpha$-D-glucopyranoside & $\mathbf{0 . 0 2}$ \\
Methyl $\beta$-D-glucopyranoside & $\mathbf{0 . 0 3}$ \\
Methyl $\alpha$-D-mannopyranoside & $\mathbf{0 . 0 2}$ \\
Methyl $\beta$-D-mannopyranoside & $\mathbf{0 . 0 3}$ \\
Methyl $\alpha$-D- $N$-acetylgalactosaminide & $\mathbf{0 . 1 1}$ \\
Methyl $\alpha$-D- $N$-acetylglucosaminide & $\mathbf{0 . 0 1}$ \\
Methyl $\beta$-D- $N$-acetylglucosaminide & $\mathbf{0 . 0 2}$ \\
Lactose & 3.8 \\
$N$-acetyllactosaminide & 2.37 \\
\hline
\end{tabular}
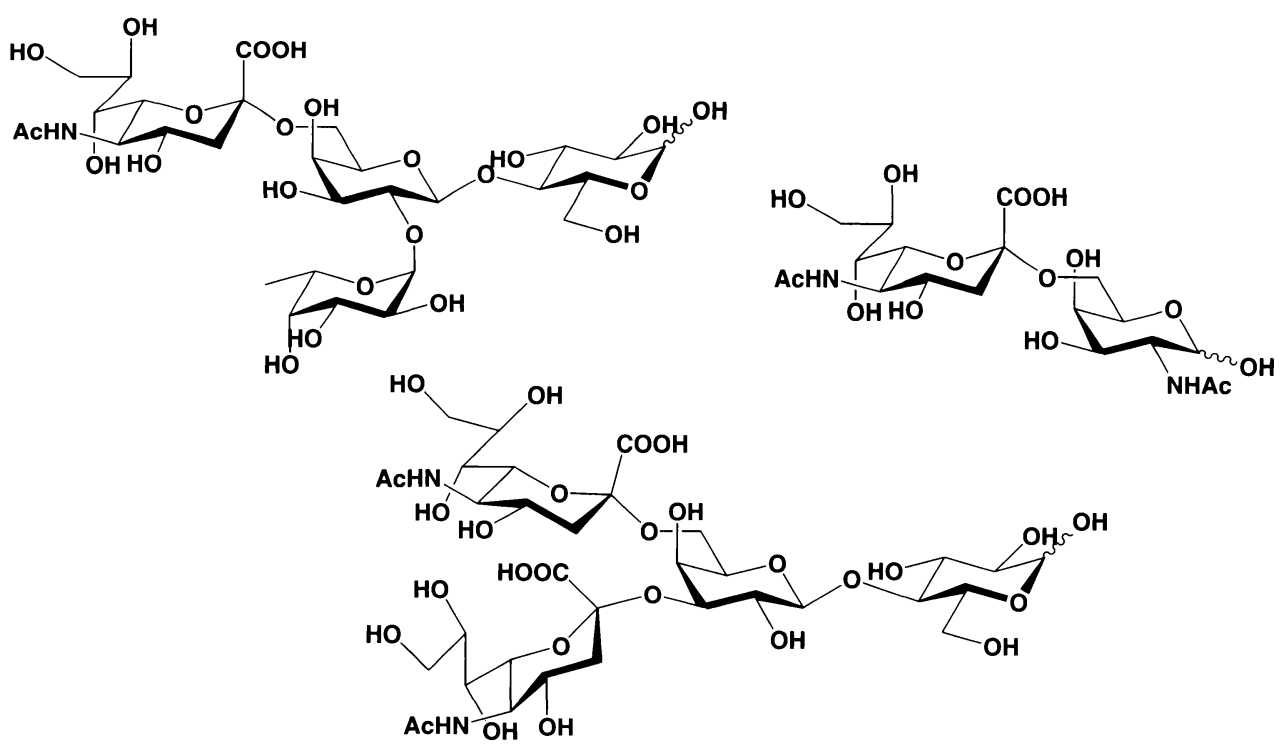

Fig. 2. Enzymatic syntheses of several sialyl-oligosaccharides using $\boldsymbol{\alpha} \mathbf{2 , 6}$-sialyltransferase produced by Photobacterium damselae JT0160. The structures of oligosaccharides were examined by ${ }^{1} \mathrm{H}$ and ${ }^{13} \mathrm{C}-\mathrm{NMR}$ spectroscopy.

thought to be membrane bound enzyme in vivo due to the fact that the enzyme was not extracted from the bacterium without detergent. We have demonstrated that this $\alpha 2,6-$ sialyltransferase had a unique acceptor substrate specificity compared with those of mammalian enzymes. This enzyme recognized both lactose and $N$-acetyllactosamine as good acceptor substrates (Table II). Furthermore, as shown in Figure 2, this $\alpha 2,6$-sialyltransferase transferred NeuAc to the galactose residue of carbohydrate chains at position 6 of 2'-fucosyl and 3'-sialyl lactose, respectively (49). This $\alpha 2,6$-sialyltransferase, as shown in Table III, also transferred $\mathrm{NeuAc}$ to both asialo- $N$-linked and asialo- $O$-linked glycoproteins (50). As to the donor substrates, this enzyme recognized not only CMP-NeuAc but also CMP-KDN (51). The kinetic parameters of this sialyltransferase for donor
ル酸転移酵素を精製して、この酵素が動物由来のシアル酸転 移醅素と比較して特長的な基質特異性を有していること、酵 素蛋白質の構造が異なること等を明らかにしてきた。具体的 には、この細菌由来の酵素はラクトース、 $N$ - アセチルラクト サミンのいずれも良い基質とした(表 II) (47)。また、この酵 素は 3'- シアリルラクトース、2'- フコシルラクトース、N-ア セチルガラクトサミンへもシアル酸を転移させること(図 2) (49)、更に、 $N$ - 結合型及び $O$ - 結合型糖蛋白質へもシアル酸 を転移させることが明らかとなった(表 III)。種々の糖鎖に 対するシアル酸転移反応を行い、この酵素の糖受容体基質特 異性を明らかにした(50)。また、この酵素は CMP-KDN を糖 供与体基質とすることも明らかにされている(51)。この酵素 の糖供与体基質、糖受容体基質に対する反応速度定数を示す (表 IV)。このシアル酸転移酵素の糖供与体基質に対する $K_{\mathrm{m}}$ 
Table III. Acceptor specificity of sialyltransferase produced by Photobacterium damselae JT0160 for glycoproteins.

\begin{tabular}{lcrr}
\hline \multirow{2}{*}{ Acceptor substrate } & \multicolumn{3}{c}{ NeuAc transferred (nmol) } \\
& Reaction time & 5 min & 60 min \\
\hline \multirow{2}{*}{ Asialo-fetuin } & 3.3 & 11.2 \\
Asialo- $\alpha_{1}$ acid glycoprotein & 3.1 & 10.9 \\
Asialo-bovine submaxillary mucin & 0.9 & 3.5 \\
\hline
\end{tabular}

\section{Table IV. Kinetic parameters of sialyltransferase produced by Photobacterium damselae JT0160.}

\begin{tabular}{lcc}
\hline Compound & $\begin{array}{c}K \text { m } \\
(\mathrm{mM})\end{array}$ & $\begin{array}{c}V \text { max } \\
\text { (units/mg) }\end{array}$ \\
\hline Donor substrate & & \\
CMP-NeuAc & 0.32 & 7.7 \\
& & \\
Acceptor substrate & & \\
Lactose & 6.82 & 6.4 \\
$N$-acetyllactosaminide & 8.95 & 9.7 \\
Methyl $\beta$-D-galactopyranoside & 174 & 6.4 \\
\hline
\end{tabular}

substrate and acceptor substrates are summarized in Table IV. The kinetic study showed the $K \mathrm{~m}$ value for the donor substrate CMP-NeuAc to be $320 \mu \mathrm{M}$, which is slightly higher than that of rat liver $\alpha 2,6$-sialyltransferase. As to acceptor substrate, its recognition of the non-reducing terminus seemed to be less strict than that of rat liver sialyltransferase. In the case of rat liver $\alpha 2,6$-sialyltransferase, the $K \mathrm{~m}$ value for the lactose is about 33-fold higher than that of $\mathrm{N}$-acetyllactosaminide. On the other hand, in the case of $\alpha 2,6$-sialyltransferase of $P$. damselae JT0160, lactose has almost the same $\mathrm{Km}$ value as $N$-acetyllactosaminide. These results indicate that $\alpha 2,6$ sialyltransferase of $P$. damselae JT0160 does not recognize the 2-acetamido group in the $N$-acetylglucosaminyl residue. In addition, the structure of $\alpha 2,6$-sialyltransferase seemed to be quite different from those of the known enzymes. Many mammalian sialyltransferases were cloned and comparison of their amino acid sequences has revealed conserved regions, which were named as the sialyl-motifs in the catalytic domains (52). However, the analysis of the $\alpha 2,6$-sialyltransferase from $P$. damselae JT0160 did not detect any regions homologous to the cloned mammalian sialyltransferases. The deduced primary sequences of the cloned mammalian sialyltransferases was predicted to carry a short amino-terminal cytoplasmic domain, a signal-membrane anchor domain, a stem region, and a large catalytic domain on the carboxy-terminal side of the mature proteins. On the other hand, when the carboxyterminus of the $\alpha 2,6$-sialyltransferase from $P$. damselae JT0160 was truncated, the protein became soluble and still retained the sialyltransferase activity. From this result, it was predicted that the catalytic domain of the enzyme was in the
值は $320 \mu \mathrm{M}$ であり、これはラット肝臓由来の $\alpha 2,6-$ シアル酸 転移酵素と比較するとやや高い值であった。一方、このシア 儿酸転移酵素の糖受容体基質の認識は、動物由来の酵素と比 較してあまり厳密ではないと考えられた。すなわち、ラット 肝臓由来の $\alpha 2,6-$ シアル酸転移酵素の場合、ラクトースに対 する $K_{\mathrm{m}}$ 值は $N$ - アセチルラクトサミニドの $K_{\mathrm{m}}$ 值と比較して 約 33 倍程度高いことが報告されているが、この酵素の場合に は、ラクトースと $N$-アセチルラクトサミニドの $K_{\mathrm{m}}$ 值はほほ 同様であった。この結果は、P. damselae JT0160 由来 $\alpha 2,6$ - シ アル酸転移酵素は $N$-アセチルラクトサミニドの 2-acetamido グループを認識していないことを示している。

P. damselae JT0160 由来 $\alpha 2,6$ - シアル酸転移酵素をコード する遺伝子の解析を行なったところ、哺乳動物由来のシアル 酸転移酵素の中で保存されているシアリルモチーフ(52)が存 在しないことが明らかとなった。またアミノ酸配列の解析結 果から、この酵素蛋白質の 3 次元構造は動物由来の糖転移醭 素とは異なることが推定された。すなわち、哺乳動物由来の シアル酸転移酵素はいずれもII 型の膜結合卜ポロジーを有し、 アミノ末端に存在する短い細胞質領域、膜結合領域、ゴルジ 内腔幹領域と酵素蛋白質のカルボキシ末端部分からなるゴル ジ内腔活性領域からなると考えられている。一方、本酵素の カルボキシ末端側に存在する、疎水性が高く大腸菌のピルビ ン酸酸化酵素と高い相同性を示す領域を欠損させた組換え酵 素を大腸菌内で発現させたところ、この組換え酵素が可溶性 酵素として生産された。この結果から、P. damselae JT0160が 生産する酵素は、そのカルボキシ末端側に膜結合領域が存 在し、触媒領域は蛋白質のアミノ末端側に存在すると想定さ れた。次に、この酵素蛋白質が活性を示すために最小のアミ 


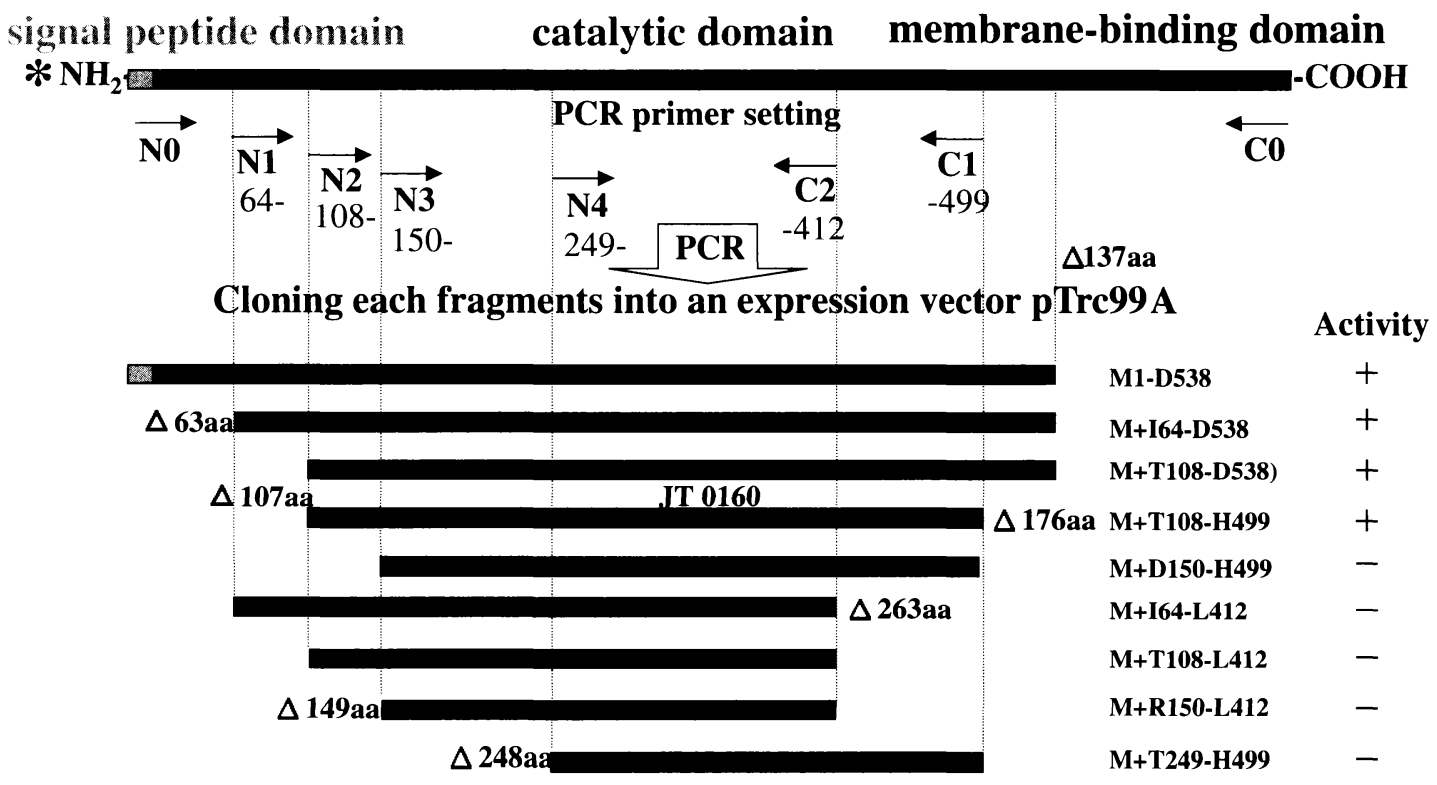

Fig. 3. Preparation of various truncated sialyltransferases and their enzyme activity. The protein lacking both $\mathrm{N}$-terminal 107 amino acids and C-terminal 176 amino acids retained the enzymatic activity. On the other hand, the deletion of N-terminal 149 amino acids or C-terminal 263 amino acids caused the complete loss of the activity. *: Full length form of $P$. damselae JT 0160 \&2,6-sialyltransferase.

amino-terminal side of the protein, and the $\alpha$-helix structures, which might be formed in the carboxy-terminal regions of the enzyme, seemed to be involved in membrane binding (24).

We then constructed a number of expression vectors, which contained a series of truncated sequences of the sialyltransferase, and proteins were produced in $E$. coli to identify portions of the protein essential for the activity. As shown in Figure 3, four of the truncated proteins showed enzyme activities. The shortest, active truncated enzyme, which lacked 107 amino acids residues from the aminoterminus and 176 amino acids residues from carboxy-terminus of the full-length enzyme was found in the soluble fraction of the lysate of the $E$. coli. The properties of the truncated enzyme were examined further, and the kinetic parameters of this protein for donor and acceptor substrate were similar to those of the native enzyme.

As of April 2006, the $\alpha 2,6$-sialyltransferase from $P$. damselae JT0160 was classified into family GT80 in the CAZy database $(53,54)$. Only two sialyltransferases with confirmed enzyme activities, $\alpha 2,6$-sialyltransferase from $P$. damselae JT0160 and $\alpha 2,3$-sialyltransferase from $P$. multocida, have so far been classified in family GT80. The way that these bacteria evolved such enzymes is of particular interest.

\section{E. $\alpha 2,3$-Sialyltransferases Produced by Several Marine Bacteria}

The results of the homology analysis of amino acid
ノ酸領域を明らかにするために、本酵素遺伝子の配列を基に 様々なプライマーを設定、本遺伝子 DNA 鋳型に PCR を行 い種々の遺伝子断片を得た後、発現べクターを構築した。そ れら発現べクターで形質転換した大腸菌を培養し、種々の truncated 酵素の活性を調べた。その結果、完全長の酵素蛋白 質から、アミノ末端から 107 アミノ酸、カルボキシ末端から 176 アミノ酸までを欠損させた 4 種類の truncated 酵素につい ては、シアル酸転移活性が確認できたが、それ以上欠損させ た場合には酵素活性が認められなかった(図 3)。また、酵素 活性を有する最も短い truncated 醰素については、酵素蛋白質 の精製を行い、酵素の性質を検討した。この truncated 酵素は、 糖受容体基質であるラクトース、糖供与体基質である CMPシアル酸に対して、P. damselae JT0160 株から精製された酵素 とほほ同様の親和性を示した。

P. damselae $\mathrm{JT} 0160$ 由来の $\alpha 2,6$ - シアル酸転移酵素は、 2006 年 4 月現在、The CAZy database では Family GT80 に分類 されている(53、54)。このグループには、機能が明らかにされ ている蛋白質としては、本酵素以外にはP. multocida 由来の $\alpha 2,3-$ シアル酸転移酵素が分類されているのみである $(25)$ 。本 酵素は、これまでに報告されている多くのシアル酸転移酵素 とは相同性が低いことから、P. damselaeがどのようにこのシ アル酸転移酵素活性を獲得したのか興味深い。

\section{E. 海洋性細菌由来 $\alpha 2,3$ - シアル酸転移酵素}

Photobacterium sp. JT-ISH-224 株由来 $\alpha 2,3$ - シアル酸転移酵 素、P. multocida 由来の $\alpha 2,3-$ シアル酸転移醭素並びに P. dam- 
sequences of $\alpha 2,6$-sialyltransferase from $P$. damselae JT0160, $\alpha 2,3$-sialyltransferases from P. multocida and $\alpha 2,3-$ sialyltransferases from Photobacterium sp. JT-ISH-224 was shown in Figure 4. In Figure 5, the extent of amino acid sequence homology among $\alpha 2,6$-sialyltransferase from $P$. damselae JT0160, $\alpha 2,3$-sialyltransferases from $P$. multocida, from $P$. phosphoreum JT-ISH-467, from Photobacterium sp. JT-ISH-224 and from Vibrio sp. JT-FAJ-16 is diagrammed. Vibrio sp. JT-FAJ-16 was the first bacterium in genus Vibrio that was reported to produce sialyltransferase. Homology between $\alpha 2,3$-sialyltransferase from Vibrio sp. JT-FAJ-16 and the one from $P$. phosphoreum JT-ISH-467 was $64.7 \%$ and homology between the ones from Vibrio sp. JT-FAJ-16 and from Photobacterium sp. JT-ISH-224 was 64.8\% (Figure 5). selae JT0160 株由来の $\alpha 2,6$ - シアル酸転移酵素のアミノ酸配列 の相同性解析結果を示す(図 4)。また、図 5 にP. phosphoreum JT-ISH-467 株、Photobacterium sp. JT-ISH-224 株及び Vibrio sp. JT-FAJ-16 株由来 $\alpha 2,3$ - シアル酸転移酵素、P. multocida 由来の $\alpha 2,3-$ シアル酸転移醅素及び P. damselae JT0160 株由来の $\alpha 2,6$ シアル酸転移酵素の相同性を示す。なお今回示すVibrio sp. JTFAJ-16 株はVibrio 属細菌としては初めて $\alpha 2,3-$ シアル酸転移 酥素を有することが明らかにされた菌株である。

Vibrio sp. JT-FAJ-16 株と P. phosphoreum JT-ISH-467 株及び Photobacterium sp. JT-ISH-224 株由来の $\alpha 2,3$ - シアル酸転移酵素 の相同性はそれぞれ.64.7\%、64.8\% と比較的高かったが、これ らと P. multocida 由来の $\alpha 2,3$ - シアル酸転移酵素との相同性は

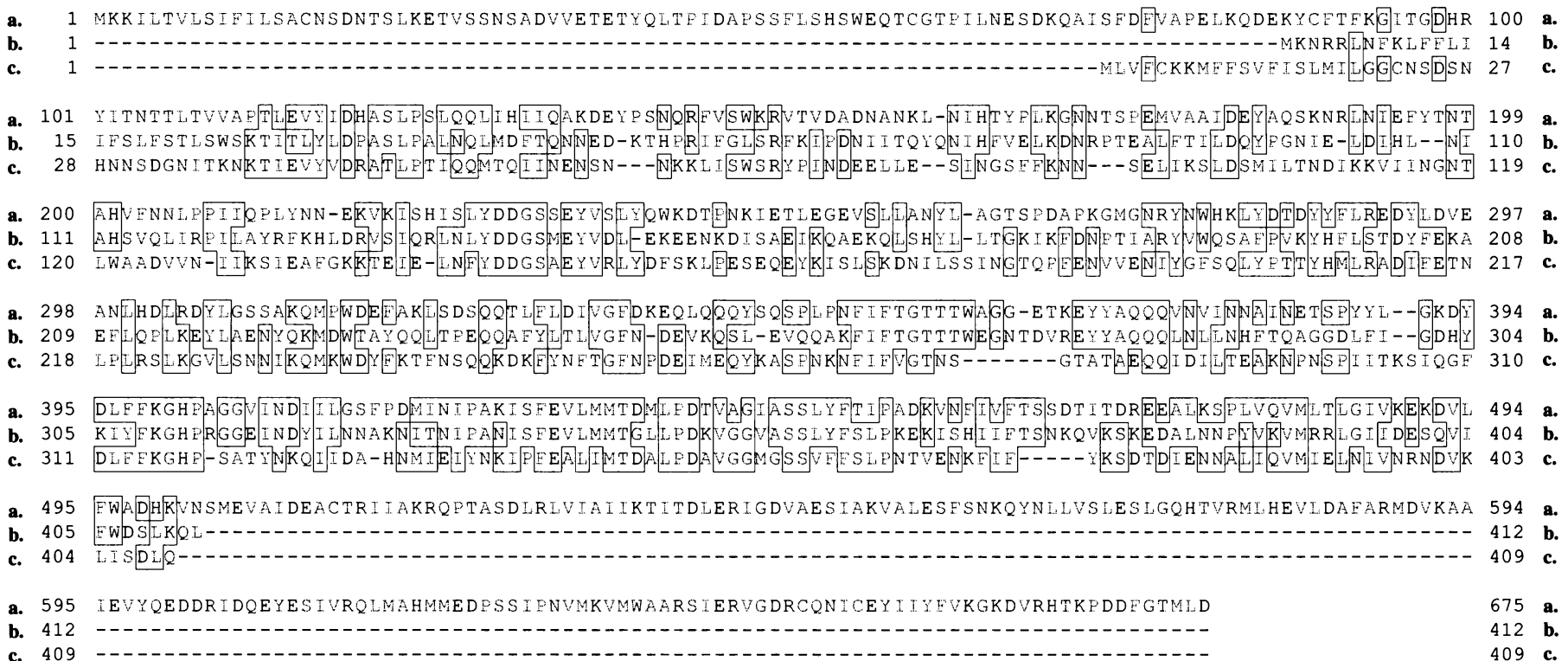

Fig. 4. Comparison of amino acid sequences of bacterial sialyltransferases. a: $\alpha 2,6$-sialyltransferase (Photobacterium damselae JT-0160), b: $\alpha 2,3$-sialyltransferase (Pasteurella multocida), c: $\alpha 2,3$-sialyltransferase (Photobacterium sp. JT-

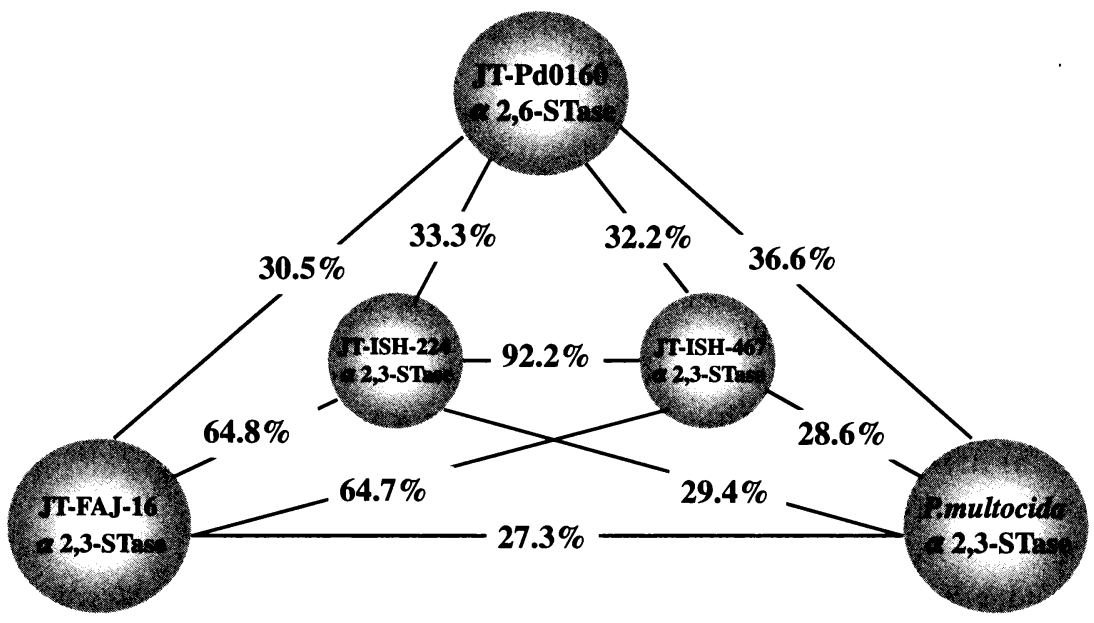

Fig. 5. Homology of bacterial sialyltransferases. 
Table V. Transfer assay of Vibrio sp. JT-FAJ-16 $\alpha 2,3$-sialyltransferase for mono- and di-saccharides.

\begin{tabular}{lc}
\hline Acceptor substrate & $\begin{array}{c}\text { NeuAc transferred } \\
(\mathbf{n m o l})\end{array}$ \\
\hline Gal $\alpha$-OMe & 10.3 \\
Gal $\beta$-OMe & 8.7 \\
GalNAc $\alpha$-OMe & 4.4 \\
Gal $\beta$ 1,3-GlcNAc $\alpha$-OMe & 9.4 \\
Lactose & 7.6 \\
LacNAc $\beta$-OMe & 9.6 \\
\hline
\end{tabular}

Incubation time: $14 \mathrm{~h}$ at $25^{\circ} \mathrm{C}$

Table VI. Acceptor specificity of the $\alpha 2,3$-sialyltransferase produced by Photobacterium phosphoreum JT-ISH-467 for oligosaccharides.

\begin{tabular}{|c|c|}
\hline Acceptor substrate & NeuAc transferred \\
\hline Galß1,4Glc-PA & + \\
\hline Gal $\beta 1,3 G a l N A c \beta 1,4 G a l \beta 1,4 G l c-P A$ & + \\
\hline $\begin{array}{r}\text { Gal } \beta 1,3 G a l N A c \beta 1,4 \\
\text { Neu5Ac } \alpha 2,3\end{array}$ Gal $\beta 1,4$ Glc-PA & + \\
\hline Gal $\alpha 1,4 G a l \beta 1,4 G l c-P A$ & + \\
\hline GalNAc $\alpha 1,3 G$ alNAc $\beta 1,3 G a l \alpha 1,4$ Gal $\beta 1,4$ Glc-PA & + \\
\hline $\begin{array}{l}\text { Gal } \beta 1,4 \text { GlcNAc } \beta 1,2 M a n \alpha 1,6 \\
\text { Gal } \beta 1,4 \text { GlcNAc } \beta 1,2 M a n \alpha 1,3\end{array}$ & + \\
\hline
\end{tabular}

However, homology between the ones from P. multocida and from Vibrio sp. JT-FAJ-16 was $27.3 \%$, homology between ones from P. multocida and from P. phosphoreum JT-ISH-467 was $28.6 \%$, and homology between ones from P. multocida and from Photobacterium sp. JT-ISH-224 was $29.4 \%$.

Acceptor substrate specificity of $\alpha 2,3$-sialyltransferase from Vibrio sp. JT-FAJ-16 for several mono- and disaccharides is shown in Table V. The anomer selectivity of this enzyme was quite low. This enzyme was able to transfer NeuAc to both methyl $\alpha$-galactopyranoside and methyl $\beta$-galactopyranoside at almost the same level. Furthermore, the enzyme transferred NeuAc to disaccharides, such as lactose and $N$-acetyllactosamine at the same level.

Acceptor substrate specificity of $\alpha 2,3$-sialyltransferase from $P$. phosphoreum JT-ISH-467 for several oligosacchrides was shown in Table VI. It was also confirmed that this enzyme was able to transfer NeuAc to asialo $\mathrm{N}$-linked glycoproteins, such as asialo-fetuin (data not shown).

The optimum pH and temperature for $\alpha 2,3$ sialyltransferase Photobacterium sp. JT-ISH-224 were 5.0 and $30^{\circ} \mathrm{C}$, respectively. Other $\alpha 2,3$-sialyltransferases from $P$. phosphoreum JT-ISH-467 and Vibrio sp. JT-FAJ-16 showed almost the same optimum $\mathrm{pH}$ and temperature, respectively.
順にそれぞれ 27.2\%、28.6\%、29.4\%であった。

ここに、Vibrio sp. JT-FAJ-16 株の組換え体 $\alpha 2,3$ - シアル酸 転移酵素の単糖、2 糖類に対するシアル酸の転移能を示す(表 $\mathrm{V})$ 。この酵素は、糖受容体基質のアノマー選択性が極めて低 く、メチル - $\alpha$ - ガラクトピラノシド、メチル - $\beta$ - ガラクトピラ ノシドにほほ同程度シアル酸を転移する。また、表 4 に示す 2 糖類に対してもほぼ同じ程度のシアル酸を転移する特徵的な 糖受容体基質特異性を有している。

P. phosphoreum JT-ISH-467 株由来の $\alpha 2,3$ - シアル酸転移酵 素の各種糖鎖に対するシアル酸転移活性を示す (表 VI)。この 酵素はアシアロフェツインのような糖蛋白質にもシアル酸を 転移する。なお、このシアル酸転移酵素の詳細な糖受容体基 質特異性は、現在検討中である。

Photobacterium sp. JT-ISH-224 株由来 $\alpha 2,3$ - シアル酸転移酵 素の至適温度と $\mathrm{pH}$ はそれぞれ $30^{\circ} \mathrm{C} 、 5.0$ である。これら 3 種 類の $\alpha 2,3-$ シアル酸転移酵素はいずれもほほ同様の至適温度及 び $\mathrm{pH}$ を有していた。

またデー夕は示さないが、いずれの酵素もその発現レベ ルは高く、いずれの酵素についても大量供給が可能である。 
The expression levels of recombinant genes have not particularly been optimized, but were already very high. In addition, we were able to successfully purify recombinant enzymes to homogeneity with very high yield. Therefore, it is now possible to supply a large amount of $\alpha 2,3$ sialyltransferases.

\section{F. Future Perspective}

In recent years, studies on carbohydrate-related enzymes of bacteria has made great progress. It seems to be quite possible that glycoproteins will be produced in further engineered prokaryotes in the near future. In addition, the supply of sugar nucleotides, such as CMP-NeuAc and UDP-Gal, which was a key limiting factor in enzymatic glycosylation, has very much improved. For example, it has been clearly demonstrated that $17 \mathrm{~g} / \mathrm{l}$ of CMP-NeuAc was produced after $27 \mathrm{~h}$ reaction starting with orotic acid and NeuAc through the coupling of recombinant $E$. coli cells overexpressing the genes of CMP-NeuAc synthetase and CTP synthetase, and Corynebacterium ammoniagenes (55). Similary, it has also been demonstrated that $44 \mathrm{~g} / l$ of UDP-Gal was produced after $21 \mathrm{~h}$ reaction starting with orotic acid and galactose (56). Moreover, several glycosyltransferases having broad acceptor substrate specificity from prokaryote are now available and the number is increasing. Thus, easy enzymatic production of glycans and/or modification of glycoconjugate at low cost have been becoming more and more widely applicable. Novel products in the pharmaceutical, food and other industries are expected to be developed aided by advancing glycotechnology.

\section{Acknowledgements}

We would like to thank Ms. H. Kajiwara and Ms. M. Ichikawa for their technical assistance.
これら 3 種類の $\alpha 2,3$ - シアル酸転移酵素の中では、Vibrio sp. JT-FAJ-16 株由来 $\alpha 2,3$-シアル酸転移酵素の生産性が最も高 かった。

\section{F. 今後の展望}

ここ数年間で微生物由来の糖質関連酵素に関する研究は 大きく進展してきた。今後の研究の進展によって、将来微生 物を用いた糖蛋白質の生産技術が構築されることも夢ではな いと考えられる。また、糖転移酵素を用いる場合に欠点とさ れていた糖供与体基質についても安価、且つ大量調製が可能 になっている。具体的には、CMP-シアル酸合成酵素と CTP 合成酵素を発現する組換え大腸菌と Corynebacterium ammoniagenes を酵素源として、オロット酸、N-アセチルノイラミン酸 を主原料として反応を行ない、反応開始から 27 時間後に反応 溶液 $1 \mathrm{~L}$ あたり $17 \mathrm{~g}$ の CMP- シアル酸が合成されることが示 されている(55)。また、同様の方法で、オロット酸とガラク トースを主原料として反応を行ない、反応開始から 21 時間後 に反応溶液 $1 \mathrm{~L}$ あたり $44 \mathrm{~g}$ の UDP-ガラクトースを合成でき ることが示されている(56)。更に本稿で示したとおり、糖受 容体基質特異性が広く、大量調製が可能なシアル酸転移醭素 も増えつつあり、簡便且つ安価なシアリル化が可能になりつ つある。今後、これらの技術を用いた医薬品や機能性食品等 が開発され、糖鎖生物学・糖鎖工学がますます発展すること を期待したい。

\section{References}

1. Varki, A. (1993) Glycobiology 3, 97-130

2. Gagneux, P., and Varki, A. (1999) Glycobiology 9, 747-755

3. Stults, C. L.M., Sweeley, C. C., and Macher, B. A. (1988) in Methods in Enzymology, vol. 179, pp.167-214

4. Burda, P., and Aebi, M. (1999) Biochim. Biophys. Acta. 1426, 230-257

5. Wakarchuk, W. W., Gilbert, M., Martin, A., WU, Y., Brisson, J. R., Thibault, P., and Richards, J. C. (1998) Eur. J. Biochem. 254, 626-633

6. Muldon, J., Shashkov, A. S., Moran, A. P., Ferrsi, J. A., Senchenkova, S. N., and Savage, A. V. (2002) Carbohydr. Res. 337, 2223-2229

7. Guerry, P., Szymanski, C. M., Prendergast, M. M., Hickey, T. E., Ewing, C. P., Pattarini, D. L., and Moran, A. P. (2002) Infect Immun. 70 (2): 787-793

8. Erickson, P. R., and Herzberg, M. C. (1993) J. Biol. Chem. 268, 23780-23783

9. Young, N. M., Brisson, J. R., Kelly, J., Watson, D. C., Tessier, L., Lanthier, P. H., Jarrell, H. C., Cadotte, N., St Michael, F., Aberg, E., and Szymanski, C. M. (2002) J. Biol. Chem. 277, 42530-42539

10. Wacker, M., Linton, D., Hitchen, P. G., Nita-Lazar, M., Haslam, S. T., North, S. J., Panico, M., Morris, H. R., Dell, A., Wren, B. W., and Aebi, M. (2002) Science 298, 1790-1793

11. Koizumi, S. (2003) Trends in Glycoscience and Glycotechnology 15, 65-74

12. Johnson, K. F. (1999) Glycoconj. J. 16, 141-146

13. Izumi, M., Shen, G. -J., Wacowish-Sgarbi, S., Nakatani, T., Plettenburg, O., and Wong, C. -H. (2001) J. Am. Chem. Soc. 123, 1090910918 
14. Izumi, M., and Wong, C. -H. (2001) Trends in Glycoscience and Glycotechnology 13, 345-360

15. Schauer, R. (1982) in Advances in carbohydrate chemistry and biology, 40, pp.131-234, Academic Press, New York

16. Schauer, R. (2004) Zoology 107, 49-64

17. Elliott, S., Lorenzini, T., Asher, S., Aoki, K., Brankow, D., Buck, L., Buese, L., Chang, D., Fuller, J., Grant, J., Hernday, N., Hokum, M., Hu, S., Knudten, A., Levin, N., Komorowski, R., Martin, F., Navarro, R., Osslund, T., Rogers, G., Rogers, N., Trail, G., and Egrie, J. (2003) Nat. Biotechnol. 21, 414-421

18. Sato, M., Furuike, T., Sadamoto, R., Fujitani, N., Nakahara, T., Nikura, K., Monda, K., Kondo, H., and Nishimura, S-I. (2004) J. Am. Chem. Soc. 126, 14013-14022

19. Jennings, M. P., Virji, M., Evans, D., Foster, V., Srikhanta, Y. N., Steeghs, L., van der, L. P., and Moxon, E. R. (1998) Mol. Microbiol. 29, 975-984

20. Power, P. M., Roddam, L. F., Dieckelmann, M., Srikhanta, Y. N., Tan, Y. C., Berrington, A. W., and Jennings, M. P. (2000) Microbiology 146, 967-979

21. Gilbert, M., Watson, D.C., Cunningham, A.M., Jennings, M.P., Young, N.M., and Wakarchuk, W.W. (1996) J. Biol. Chem. 271, 2827128276

22. Gilbert, M., Brisson, J.R., Karwaski, M.F., Michniewicz, J., Cunningham, A.M., Wu, Y., Young, M., and Wakarchuk, W.W. (2000) J. Biol. Chem. 275, 3896-3906

23. Shen, G.J., Datta, A.K., Izumi, M., Koeller, K.M., and Wong, C.-H. (1999) J. Biol. Chem. 274, 35139-35146

24. Yamamoto, T., Nakashizuka, M., and Terada, I. (1998) J. Biochem. 123, 94-100

25. Yu, H., Chokhawala, H., Karpel, R., Bingyuan, H. Y., Zhang, J., Zhang, Y., Jia, Q., and Chen, X. (2005) J. Am.Chem. Soc. 127, 1761817619

26. Hood, D.W., Cox, A.D., Gilbert, M., Makepeace, K., Walsh, S., Deadman, M.E., Cody, A., Martin, A., Mansson, M., Schweda, E.K.H., Brisson, J.-R., Richards, J.C., Moxon, E.R., and Wakarchuk, W.W. (2001) Mol. Microbiol. 39, 341-350

27. Jones, P.A., Samuels, N.M., Phillips, N.J., Munson, R.S. Jr., Bozue, J.A., Arseneau, J.A., Nichols, W.A., Zaleski, A., Gibson, B. W., and Apicella, M.A. (2002) J. Biol. Chem. 277, 14598-14611

28. Chaffin, D.O., McKinnon, K., and Rubens, C.E. (1996) Mol. Microbiol. 45, 109-122

29. Chiu, C. P. C., Watts, A. G., Lairson, L. L., Gilbert, M., Lim, D., Wakarchuk, W. W., Withers, S. G., and Strynadka, N. C. (2004) Nat. Struct. Biol. 11, 163-170

30. Ni, L., Sun, M., Yu, H., Chokhawala, H., Chen, X., and Fisher, A. J. (2006) Biochemistry 45, 2139-2148

31. Gotschlich, E. C. (1994) J. Exp. Med. 180, 2181-2190

32. Wakarchuk, W.W., Martin, A., Jennings, M.P., Moxon, E.R., and Richards, J.C. (1996) J. Biol. Chem. 271, 19166-19173

33. Gilbert, M., Brisson, J.R., Karwaski, M.F., Michniewicz, J., Cunningham, A.M., Wu, Y., Young, M., and Wakarchuk, W.W. (2000) J. Biol. Chem. 275, 3896-3906

34. Watanabe, M., Miyake, K., Yanae K., Kataoka, Y., Koizumi, S., Endo, T., Ozaki, A., and Iijima, S. (2002) J. Biochem. 131, 183-191

35. Riley, J. G., Menggad, M., Montoya-Peleaz, P. J., Szarek, W. A., Marolda, C.L., Valvano, M.A., Schutzbach, J. S., and Brockhausen, I. (2005) Glycobiology 15, 605-613

36. Endo, T., Koizumi, S., Tabata, K., and Ozaki, A. (2000) Glycobiology 10, 809-813

37. Kolkman, M.A.B., Wakarchuk, W.W., Nuijten, P.J.M., and van der Zeijst, B.A.M. (1997) Mol. Microbiol. 26, 197-208

38. Ge, Z., Chan, N.W.C., Palcic, M.M, and Taylor, D.E. (1997) J. Biol. Chem. 272, 21357-21363

39. Wang, G., Boulton, P.G., Chan, N.W.C., Palcic, M.M, and Taylor, D.E. (1999) Microbiology 145, 3245-3253

40. Rasko, D.A., Wang, G, Palcic, M.M, and Taylor, D.E. (2000) J. Biol. Chem. 275, 4988-4994

41. Quinto, C., Wijfjes, A. H., Bloemberg, G. V., Blok-Tip, L., Lopez-Lara, I. M., Lugtenberg, B. J., Thomas-Oates, J. E., and Spaink, H. P. (1997) Proc. Natl. Acad. Sci. USA 94, 4336-4341

42. Quesada-Vincens, D., Fellay, R., Nasim, T., Viprey, V., Burger, U., Prome, J. C., Broughton, W. J., and Jabbouri, S. (1997) J. Bacteriol. 179, 5087-5093

43. Jennings, M.P., Hood, D.W., Peak, I.R.A., Virji, M., and Moxon, E. R. (1995) Mol. Microbiol. 18, 729-740

44. Sun, S., Scheffler, N. K., Gibson, B. W., Wang, J., and Munson, R. S. Jr. (2002 ) Infect Immun. 70, 5887-5892

45. Wang, Q. M., Peery, R. B., Johnson, R. B., Alborn, W. E., Yeh, W. K., and Skatrud, P. L. (2001) J. Bacteriol. 183, $4779-4785$

46. Shao, J., Zhang, J., Kowal, P., Lu, Y., and Wang, P. G. (2002) Biochem. Biophys. Res. Commun. 295, 1-8

47. Yamamoto, T., Nakashizuka, M., Kodama, H., Kajihara, Y., and Terada, I. (1996) J. Biochem. 120, $104-110$

48. Wakarchuk, W.W., Watson, D., Michael, F. St., Li, J., Wu, Y., Brisson, J.-R., Young, N.M., and Gilbert, M. (2001) J. Biol. Chem. 276, $12785-12790$

49. Kajihara, Y., Yamamoto, T., Nagae, H., Nakashizuka, M., Sakakibara, T., and Terada, I. (1996) J. Org. Chem. 61, 8632-8635

50. Yamamoto, T., Nagae, H., Kajihara, Y., and Terada, I. (1998) Biosci. Biotechnol. Biochem. 62, 210-214

51. Kajihara, Y., Akai, S., Nakagawa, T., Sato, R., Ebata, T., Kodama, H., and Sato, K. (1999) Carbohydr. Res. 315, 137-141

52. Datta, A. K., Sinha, A., and Paulson, J. C. (1998) J. Biol. Chem. 273, 9608-9618

53. Coutinho, P.M., Deleury, E., Davies, G. J., and Henrissat, B (2003) J. Mol. Biol. 328, 307-317

54. Campbell, J. A., Davies, G. J., Bulone, V., and Henrissat, B (1997) Biochem. J. 326, 929-939

55. Endo, T., Koizumi, S., Tabata, K., and Ozaki, A. (2000) Appl. Microbiol. Biotechnol. 53, 213-217

56. Koizumi, S., Endo, T., Tabata, K., and Ozaki, A. (1998) Nat. Biotechnol. 16, 847-850 


\section{Profile of the Authors}

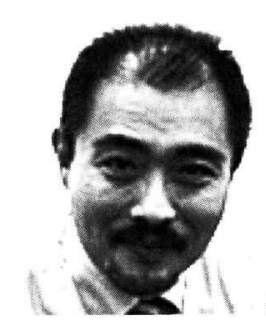

Takeshi Yamamoto was born in Hokkaido in 1966. Graduated from Yamagata University, School of Agriculture in 1989 and received his master degree in 1991 from Yamagata University, Graduate School of Agricultural Chemistry. He obtained his Ph.D. degree in 1998 from Iwate University, Graduate School of Agriculture. He has been working for Japan Tobacco Inc. since 1991.

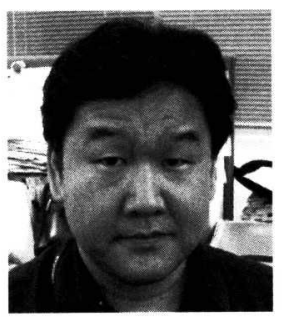

Yoshimitsu Takakura graduated from Hokkaido University in 1992, started his professional career as researcher at the Japan Tobacco Inc. in the field of plant genetic engineering and microbial biotechnology, and received his Ph. D. from the same University. He is Senior Research Scientist at Glycotechnology Business Unit of Japan Tobacco Inc. His current interests are the development of Bio-sensing device using biologically active molecules and his daughter's growth.

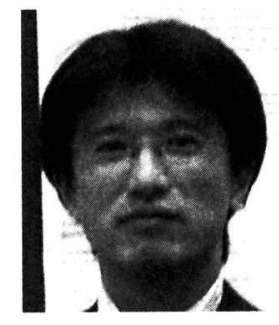

Hiroshi Tsukamoto received his MS from the Faculty of Agriculture, Okayama University in 1990. He then worked in the plant pathology field as research scientist at Japan Tobacco Inc. for more than 10 years, and received his $\mathrm{PhD}$ from the Faculty of Agriculture, Kyoto University in 2000. Since 2003, he has studied glycosyltransferases in microorganisms at Glycotechnology Business Unit, Japan Tobacco Inc. 